\title{
Control of Reactive Oxygen Species through Antioxidant Enzymes Plays a Pivotal Role during the Cultivation of Neopyropia yezoensis
}

\author{
Zezhong Feng ${ }^{1,2}$, Lingjuan $\mathrm{Wu}^{3}$, Zhenjie Sun ${ }^{1,2}$, Jiali Yang ${ }^{2}$, Guiyan Liu ${ }^{3}$, Jianfeng Niu ${ }^{2,4,5, *}$ \\ and Guangce Wang $2,4,5, *$
}

Citation: Feng, Z.; Wu, L.; Sun, Z.; Yang, J.; Liu, G.; Niu, J.; Wang, G. Control of Reactive Oxygen Species through Antioxidant Enzymes Plays a Pivotal Role during the Cultivation of Neopyropia yezoensis. J. Mar. Sci. Eng. 2022, 10, 109. https://doi.org/ 10.3390/jmse10010109

Academic Editor: Azizur Rahman

Received: 21 November 2021

Accepted: 30 December 2021

Published: 14 January 2022

Publisher's Note: MDPI stays neutral with regard to jurisdictional claims in published maps and institutional affiliations.

Copyright: () 2022 by the authors Licensee MDPI, Basel, Switzerland. This article is an open access article distributed under the terms and conditions of the Creative Commons Attribution (CC BY) license (https:/ / creativecommons.org/licenses/by/ $4.0 /)$.
1 Marine Science and Engineering College, Qingdao Agricultural University, Qingdao 266109, China; fengzezhong@qdio.ac.cn (Z.F.); sunzhenjie@qdio.ac.cn (Z.S.)

2 Key Laboratory of Experimental Marine Biology, Institute of Oceanology, Chinese Academy of Sciences, 7 Nanhai Road, Qingdao 266071, China; jialiyang21@m.fudan.edu.cn

3 North China Sea Marine Forecasting Center, State Oceanic Administrator, Qingdao 266033, China; wulingjuan@ncs.mnr.gov.cn (L.W.); liuguiyan@ncs.mnr.gov.cn (G.L.)

4 Laboratory for Marine Biology and Biotechnology, Pilot National Laboratory for Marine Science and Technology (Qingdao), 168 Wenhai Middle Road, Qingdao 266237, China

5 Center for Ocean Mega-Science, Chinese Academy of Sciences, 7 Nanhai Road, Qingdao 266071, China

* Correspondence: jf_niu@qdio.ac.cn (J.N.); gcwang@qdio.ac.cn (G.W.); Fax: +86-532-82880645

\begin{abstract}
Neopyropia yezoensis is an economically important marine crop that can survive dehydrating conditions when nets are lifted from seawater. During this process, production of oxygen radicals and the resulting up-regulation of antioxidant enzymes mediated by the abscisic acid (ABA) signaling pathway played an important role. However, there were no reports about the significance regarding the protection of seaweed throughout the entire production season. Especially, in new aquatic farms in Shandong Province that were formed when traditional N. yezoensis cultivation moved north. Here, we determined the levels of ABA, hydrogen peroxide $\left(\mathrm{H}_{2} \mathrm{O}_{2}\right)$, soluble protein, chlorophyll, and cell wall polysaccharides in samples collected at different harvest periods from Jimo aquatic farm, Shandong Province. The activities and expression of NADPH oxidase (NOX) and antioxidant enzymes in the corresponding samples were also determined. Combined with the monitoring data of sea surface temperature and solar light intensity, we proposed that the cultivation of $N$. yezoensis in Shandong Province was not affected by high-temperature stress. However, photoinhibition in $N$. yezoensis usually occurs at noon, especially in March. Both the activities and the expression of NOX and antioxidant enzymes were up-regulated continuously. It is reasonable to speculate that the reactive oxygen species (ROS) produced by NOX induced the up-regulation of antioxidant enzymes through the ABA signaling pathway. Although antioxidant enzymes play a pivotal role during the cultivation of $N$. yezoensis, the production of ROS also caused a shift in gene expression, accumulation of secondary metabolites, and even decreased the chlorophyll pool size, which eventually led to a decrease in algae assimilation. Accordingly, we suggest that the dehydration of $N$. yezoensis nets should be adopted when necessary and the extent of dehydration should be paid special consideration to avoid an excessive cellular response caused by ROS.
\end{abstract}

Keywords: Neopyropia yezoensis; antioxidase; reactive oxygen radicals; abscisic acid; stress response; ABA signaling pathway

\section{Introduction}

Reactive oxygen species (ROS), constituting the superoxide anion $\left(\mathrm{O}^{2-}\right)$, singlet oxygen, hydroxyl radical $(\mathrm{OH} \cdot)$, and hydrogen peroxide $\left(\mathrm{H}_{2} \mathrm{O}_{2}\right)$, are byproducts of cellular metabolism [1,2]. They are highly reactive molecules and their accumulation is thought to be harmful to cellular components because of the potential oxidation to the biomacromolecules. ROS overproduction usually causes an imbalance of that cell redox state, termed 
as 'oxidative stress', which may result in cell death [1-3]. Fortunately, the levels of ROS are efficiently constrained by both enzymatic and non-enzymatic antioxidants [4] when the organisms were subjected to diverse biotic and abiotic stresses [2-5]. However, it is now widely accepted that ROS is also involved in a variety of fundamental plant processes, such as signals used for plant growth and development [5], response to environmental changes, and the modulation of gene expression.

Neopyropia yezoensis belongs to the Bangiaceae family, Bangiales order, Bangiophycidae class, Rhodophyceae phylum, Rhodophyta and is widely distributed on reefs in the coastal intertidal zone. As a typical ancient lineage of red algae, it has simple morphology with a monolayer cell structure that can survive periodical cycles of dehydration and rehydration [6]. At low tide, N. yezoensis is exposed to air and can lose as much as $90 \%$ of its cellular water [7]; however, its functional activities can completely recover when rehydrated. During the whole life history stage from autumn to the following spring, the algae are subjected to multiple environmental stresses, consisting of temperature shock, cold, salt, dehydration, and irradiance stresses [8-10]. This suggests that there must be some protective adaptation mechanisms in N. yezoensis that effectively avoids the damage caused by these extreme stress conditions. The protective mechanisms mainly include antioxidant reactions [11], peroxidation repair [12], and degradation of D1 protein in photosystem II reaction centers [13]. The results of our previous study suggested that multiple antioxidant enzymes and antioxidant molecules are vital to the survival of N. yezoensis in the extremely volatile environments of the intertidal zone [14]. Both the activity and the expression of specific antioxidases increased significantly after the addition of exogenous ABA to the algae when the algae are subjected to high salinity. Thus, it is proposed that the up-regulation of antioxidase genes under high salinity conditions may be mediated by the abscisic acid (ABA) signaling pathway. During the process, NADPH oxidase (NOX) may play an important role in the induction of the ABA signaling pathway.

Pyropia is cultivated mainly in China, Japan, and South Korea. According to the data from the Food and Agriculture Organization of the United Nations, the annual output of Chinese Pyropia from 2017 to 2020 has increased greatly. In Jiangsu Province of China, the production of $N$. yezoensis has become one of the pillar industries in local aquaculture [15]. With the expansion in the scale of production, Pyropia cultivation is currently facing many problems, including the degradation of sea areas, reduction caused by disease, and lack of germplasm resources. Moreover, global warming in recent years has led to a continual increase in seawater temperature. Affected by this, migration to the north coast of Shandong Province has gradually become a new trend in N. yezoensis cultivation.

During the daily management of cultivation, nets with algae are lifted from water regularly or irregularly so that algae bodies often experience stress from water loss, strong light irradiation, and temperature shock. This stress may cause a shift in cellular metabolism and thereby changes to cell compositions. Several reports analyzing the quality and nutrition of N. yezoensis at different harvest periods have been published. It was found that the content of protein in $N$. yezoensis gradually decreased with the extension of cultivation time [16]. Nutrient analysis of the algae at different harvest periods revealed that lysine, threonine, and valine gradually increased with the harvest period; the flavor amino acids increased also with the increase of the harvest period [17]. The fatty acid content in different harvest periods was the highest in February and similar in January and March. However, it is unclear what causes shifts in the metabolism and accumulation of cell components throughout the entire cultivation season. Whether the synthesis of ABA is inhibited with the aging of the seaweed, and whether the antioxidant enzyme activities are also affected, and thus led to the damage of algal cells, remains to be determined.

\section{Materials and Methods}

\subsection{Observation of Sea Surface Temperature (SST) and Simulated Solar Light Intensity}

SST was obtained from hourly observations at the Tianheng Ocean Station from 1 November 2020 to 31 March 2021. The data is subject to quality control such as format, 
range, continuity and correlation tests [18]. The daily averaged temperature was calculated from the hourly observed data.

Solar light intensity was obtained from the simulated solar short-wave radiation data in the Weather Research and Forecasting model [19]. The model included three domains: the East China Sea, Yellow and Bohai Seas, and coastal waters of Qingdao, with double nesting. The spatial resolution of Qingdao offshore was $3 \mathrm{~km}$. The prediction process adopted Euler mass coordinates, Lambert projection mode, and 3 Runge-Kutta time integration schemes with a vertical direction of $30 \sigma$ layers. The initial field and lateral boundary conditions used in the model were global forecasting data with a time interval of $6 \mathrm{~h}$ (Global Forecasting System, horizontal resolution $1^{\circ} \times 1^{\circ}$ ) provided by the National Center for Environmental Prediction. The model used a WRF-3DVAR operational assimilation module to realize 24-h time-window assimilation of the upper air station, ground station, ship, ocean station, buoy, and satellite data. Thus, the initial field quality of the model was greatly improved. Hourly simulated solar short-wave radiation was the output. The maximum of each day was screened to obtain the daily maximum, while the change in the trend line of solar short-wave radiation was obtained by using two polynomial curve fitting methods.

\subsection{Collection of Algae Materials}

Fresh N. yezoensis thalli were provided by the algae culture farm in the Jimo area $\left(36^{\circ} \mathrm{N}\right.$, $120^{\circ}$ E), Shandong Province, China. From November 2020 to March 2021, the samples were collected once a month from the breeding nets in the stay-pole raft mode. All the cultivated samples collected were those that had been completely immersed for several days and were due to be harvested. The collected algae were put into the incubator and brought back to the laboratory as soon as possible. Then, the relatively intact and clean algae were washed with seawater, absorbed with paper, and frozen in $1.5 \mathrm{~mL}$ centrifuge tubes with liquid nitrogen. On average, each tube contained about $1 \mathrm{~g}$ of fresh algae, and a total of 10 tubes were collected each month. The packaged samples were stored at $-80^{\circ} \mathrm{C}$ for later use.

\subsection{Determination of Soluble Protein, Chlorophyll, and Cell Wall Polysaccharides}

All the samples (about $100 \mathrm{mg}$ FW) collected at a different cultivation period were frozen in liquid nitrogen and ground by grinders (Jingxin Technology, Shanghai, China) in $2 \mathrm{~mL}$ grinding tubes. Equal amounts of PBS buffer ( $\mathrm{pH}$ 7.4) were added sequentially and the algal homogenates were then centrifuged for $10 \mathrm{~min}$ at $12,000 \times g$ and $4{ }^{\circ} \mathrm{C}$; the supernatant was collected and another round of extraction was performed. All the supernatants of each sample were combined as the soluble protein extracts. The remaining precipitates were added to a $1 \mathrm{~mL}$ volume of $80 \%$ acetone, fully vibrated and extracted overnight at $-20^{\circ} \mathrm{C}$. Then, the extracts were centrifuged for $5 \mathrm{~min}$ and $12,000 \times \mathrm{g}$ at $4{ }^{\circ} \mathrm{C}$ and the supernatants were collected for the quantification of chlorophyll.

The soluble protein concentration was determined according to the BCA method using spectrophotometry at $562 \mathrm{~nm}$. The absorbance of the chlorophyll extracts at specified wavelengths was measured by a spectrophotometer (UV-1900, SHIMADZU, Suzhou, China) and the total chlorophyll was calculated based on the formula as follows [20]

$$
\mathrm{C}_{\mathrm{T}}=\mathrm{Chla}+\mathrm{Chlb}=8.02 \times \mathrm{OD}_{663}+20.21 \times \mathrm{OD}_{645}
$$

The homogenates of different cultivation periods were obtained as above and then centrifuged for $10 \mathrm{~min}$ at $12,000 \times g$ and $4{ }^{\circ} \mathrm{C}$. The supernatant was discarded and the precipitates obtained were washed with distilled water two times and recovered by centrifugation for $10 \mathrm{~min}$ at $4{ }^{\circ} \mathrm{C}$. The resultant precipitates were added to $0.5 \mathrm{M} \mathrm{HCl}$ for hydrolyzation for $2 \mathrm{~h}$ at $50{ }^{\circ} \mathrm{C}$ and incubated at room temperature overnight. Then, the same volume of $0.5 \mathrm{M} \mathrm{NaOH}$ was added to make cell wall hydrolysates appear alkaline. The determination was conducted using a microplate reader (Infinite ${ }^{\circledR}$ M1000 Pro, Tecan, Switzerland) at $500 \mathrm{~nm}$ following the manufacturer's instructions. The absorbance values were used to calculate the reduced sugar contents in different samples using a standard curve of glucose. 


\subsection{Determination of $A B A$ Content}

The change of ABA content in N. yezoensis at different cultivation periods was determined by using a Plant Abscisic Acid Elisa Assay Kit (Nanjing Jiancheng Bioengineering Institute, Nanjing, China) in a microplate reader (Infinite ${ }^{\circledR}$ M1000 Pro, Tecan, Switzerland). The absorbance value was negatively correlated with the concentration of ABA in the sample. As required by the instructions, about $100 \mathrm{mg}$ of the FW sample was put into a $2.0 \mathrm{~mL}$ grinding tube. The supernatant for ABA detection was obtained by the same method as the protein extract above.

A volume of extract $(50 \mu \mathrm{L})$ was added to the enzyme-labeled well precoated with capture antibody and biotinylated labeled antigen was added. The mixture was incubated for 30 min at $37^{\circ} \mathrm{C}$, washed with PBST, and then avidin-HRP, which can bind to biotin, was added and incubated for another $30 \mathrm{~min}$ at $37^{\circ} \mathrm{C}$, and washed with PBST again. The chromatin reaction was carried out for $10 \mathrm{~min}$ at $37^{\circ} \mathrm{C}$ and scaled at $450 \mathrm{~nm}$ using a microplate reader (Infinite ${ }^{\circledR}$ M1000 Pro, Tecan, Switzerland).

\subsection{Assay of Antioxidant Enzymes}

The total antioxidant capacity and the activities of antioxidant enzymes ascorbate peroxidase (APX), superoxide dismutase (SOD), peroxidase (POD), and catalase (CAT) were measured using an assay kit (Nanjing Jiancheng Bioengineering Institute, Nanjing, China). The method for obtaining the crude protein extract was the same as above. The kit for the determination of NOX activity was provided by Suzhou KeMing Biotechnology and the sample processing and determination were carried out following the instructions.

\subsection{RNA Extraction, cDNA Library Construction, and Real-Time PCR Assay}

Total RNA of each sample was extracted using an RNAprep Pure Plant Kit (Tiangen, Beijing, China) according to the manufacturer's instructions. The RNA integrity was checked by $1 \%$ agarose gel electrophoresis and the concentration and purity of the RNA were detected by using a NanoPhotometer NP80 Touch (Implen Gmbh, Munich, Germany). Then, $200 \mathrm{ng}$ of RNA obtained from each sample was reverse transcribed using a Takara reverse transcriptase kit (Takara, Japan).

The sequences of antioxidant enzyme genes were screened, and the sequences were downloaded from NCBI, primers were designed (Table 1). The amplification conditions were optimized and a quantitative experiment was conducted on a StepOne Plus Multicolor Real-Time (ABI, Foster, CA, USA). The GAPDH gene was used as the internal control gene. Each reaction contained $10 \mu \mathrm{L} 2 \times$ SYBR Green Master Mix (Roche, Germany). Three parallel determinations were set for each sample and the relative gene expression values of the target enzymes in different months were calculated using the $2^{-\Delta \Delta C t}$ method [21].

Table 1. Information about the genes and primers used in this study.

\begin{tabular}{|c|c|c|c|}
\hline Gene Name & Gene Introduction & Primer Sequence $5^{\prime}-3^{\prime}$ & Product Length \\
\hline GAPDH & glyceraldehyde-3-phosphate dehydrogenase & $\begin{array}{l}\text { CCAACAAGTGGGAGTAAGCG } \\
\text { GGACAGAACCGAACAGCGTA }\end{array}$ & 104 \\
\hline$S O D$ & Superoxide dismutase & $\begin{array}{l}\text { GGCTGCCTGCCTTTGACA } \\
\text { CTCGTAGGTGCTCCGTTG }\end{array}$ & 438 \\
\hline$A P X$ & Ascorbate peroxidase & $\begin{array}{l}\text { AGATTATGAAGGAGACGC } \\
\text { AAAAGAATGGACAGGAAG }\end{array}$ & 372 \\
\hline NOX & NADPH oxidase & $\begin{array}{l}\text { GAGCACCССССТGTCCATC } \\
\text { GGCGAGCACAAATCCCGTC }\end{array}$ & 167 \\
\hline$C A T$ & Catalase & $\begin{array}{l}\text { CCСTCTCTGCCCTTCACA } \\
\text { CTTCCCGTAGCCGTCCTC }\end{array}$ & 192 \\
\hline
\end{tabular}

\subsection{Detection of $\mathrm{H}_{2} \mathrm{O}_{2}$, Malondialdehyde (MDA) and the Mycosporine-like Amino Acids Content}

Corresponding detection kits (Nanjing Jiancheng Bioengineering Institute, Nanjing, China) were used to determine the content of $\mathrm{H}_{2} \mathrm{O}_{2}$ and malondialdehyde (MDA) through 
spectrophotometry. The extraction steps referred to the descriptions detailed above. The protein concentration was determined by the BCA method as mentioned above. Hydrogen peroxide content was calculated by measuring the amount of complex produced by $\mathrm{H}_{2} \mathrm{O}_{2}$ in a molybdic acid reaction at $405 \mathrm{~nm}$. The content of MDA could be calculated by measuring the absorbance of the reaction system at $530 \mathrm{~nm}$.

The homogenates of different cultivation periods were obtained through grinding with liquid nitrogen and an appropriate volume of $2.4 \mathrm{M}$ methanol solution were added, then fully mixed and extracted for $30 \mathrm{~min}$ at $60{ }^{\circ} \mathrm{C}$ and centrifuged at $12,000 \times \mathrm{g}$ and $4{ }^{\circ} \mathrm{C}$ for $20 \mathrm{~min}$. The supernatants were collected as much as possible and the absorbance value at $333 \mathrm{~nm}$ was determined. The relative contents of Mycosporine-like amino acids (MAAs) were calculated using the following formula [22].

$$
\mathrm{C}_{\text {MAAs }}=\mathrm{A} /\left(\varepsilon \times \mathrm{C}_{\mathrm{pr}}\right)
$$

where $A$ is the absorbance value at $333 \mathrm{~nm}, \varepsilon$ is the extinction molar coefficient $4 \mathrm{~mL} \mathrm{~cm}^{-1} \mathrm{mg}^{-1}$, and $C_{\mathrm{pr}}$ is the protein concentration.

\subsection{Statistical Analysis}

All determinations were repeated three times and the data were presented as the average measurements \pm SD. Statistical analysis was performed using SPSS 26.0 (https: / / www.ibm.com accessed on 30 September 2021, and significant difference was determined using Duncan's test $(p<0.05)$.

\section{Results}

\subsection{Variation in SST and Solar Light Intensity}

As shown in Figure 1, the SST decreased gradually from early November to January 1, and the samples collected in November and December did not experience the effect of an abnormal temperature increase. Between 1 and 15 January, a large fluctuation of SST was recorded. Then, from mid-February to late March, the SST rose continuously from $4{ }^{\circ} \mathrm{C}$ to $10{ }^{\circ} \mathrm{C}$. The SST was $12.5^{\circ} \mathrm{C}$ when the sample was collected in November and was maintained at $4{ }^{\circ} \mathrm{C}$ during the collection of the samples in December and January. Then, the samples were collected when the SST was about $5{ }^{\circ} \mathrm{C}$ in February and increased to $10^{\circ} \mathrm{C}$ in March. The hourly light intensity of the seawater surface during the same period is shown in Figure 2 . The fitted light intensity curve showed that it fell slowly from November to the end of December, then continued to rise faster and faster to about $800 \mathrm{~W} \mathrm{~m}^{-2}$ at the end of March.

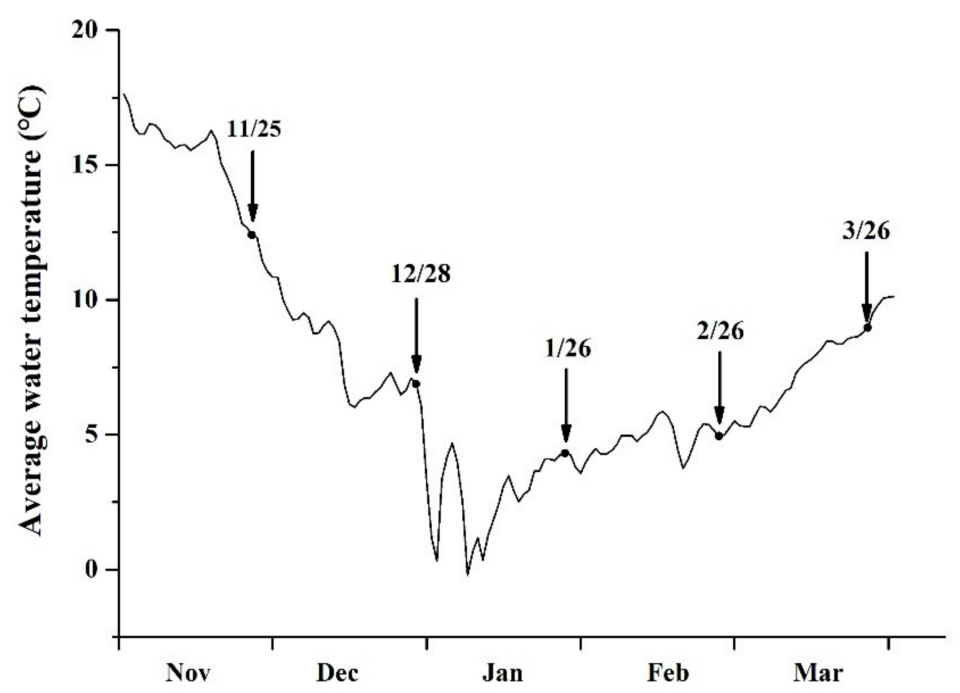

Figure 1. Variation of the sea surface temperature from November 2020 to March 2021 in Jimo sea area. 


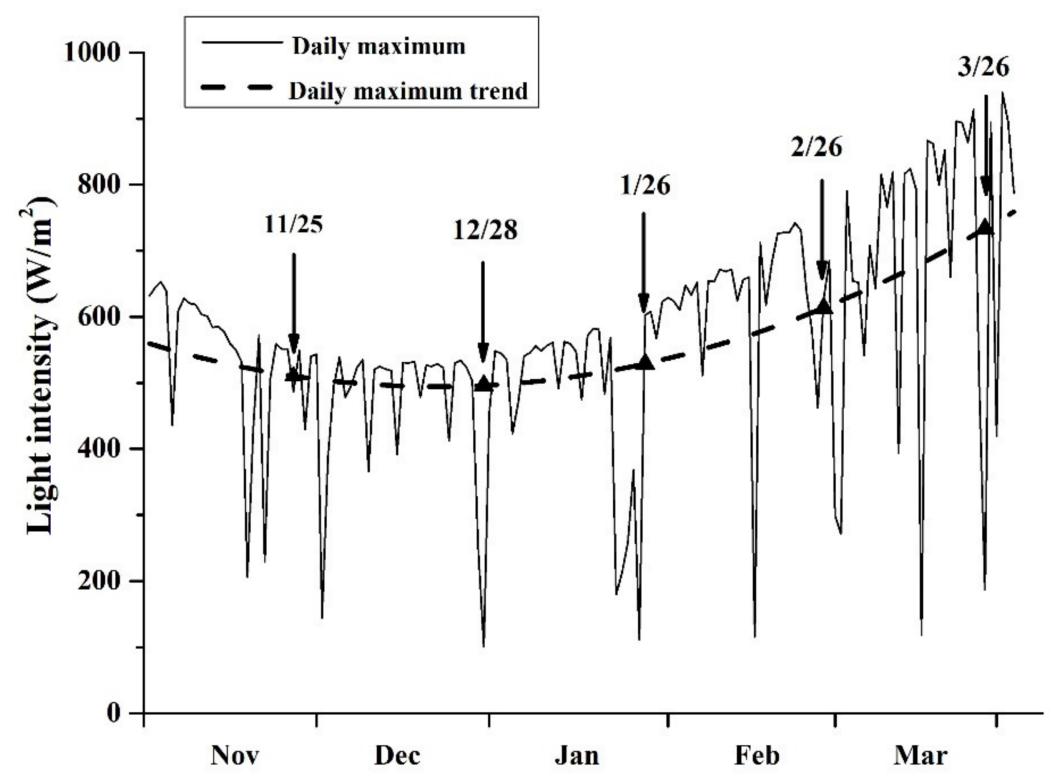

Figure 2. The hourly solar light intensity from November 2020 to March 2021 in Jimo sea area. The solar light intensity values were obtained from the simulated solar short-wave radiation data. The points marked in the figure were the sampling date.

The points marked in the figure were the sampling date.

\subsection{Changes to the Protein, Chlorophyll, and Cell Wall Polysaccharides under Different Cultivation Periods}

As shown in Figure 3a, in the early stage of cultivation, the ratio of soluble protein content in algae weight can reach $16 \%$ and the total soluble protein contents decreased with the cultivation periods. During the middle stage of cultivation, it decreased to just above half of the original level. Then, the protein content decreased sharply from February to March, and was about $45 \%$ and $25 \%$ of that in November, respectively.
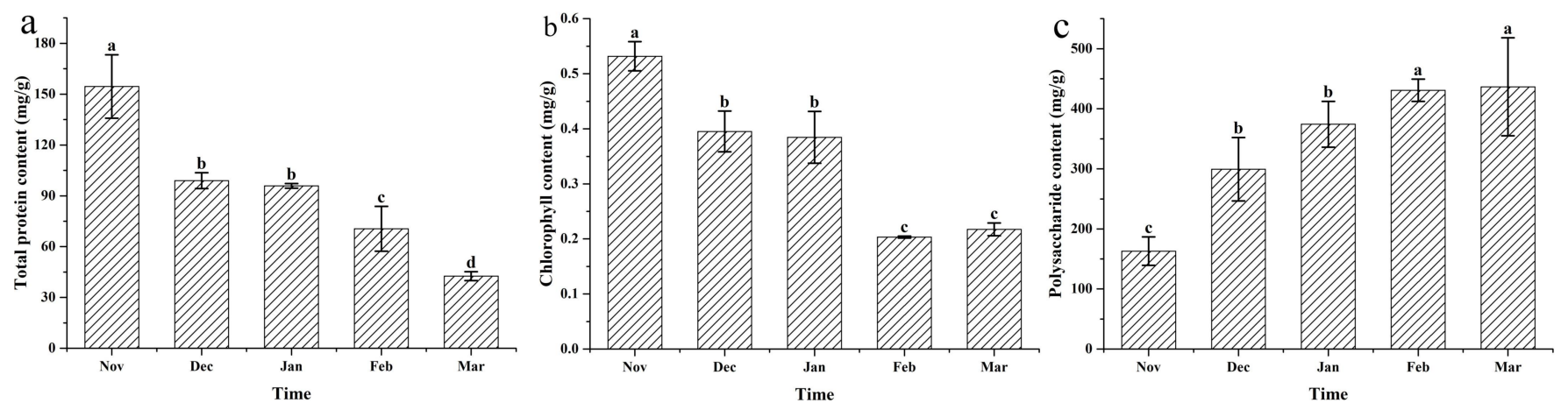

Figure 3. Quantity analysis of N. yezoensis samples at different harvest periods. (a) Total soluble protein content; (b) ChlorophyII content; (c) Cell wall hydrolyzed polysaccharides. Data were Mean \pm SD $(n=3)$. Different letters indicated significant differences $(p<0.05)$.

Overall, the chlorophyll content changes showed a trend similar to that of the soluble total protein of gradually decreasing. However, it decreased less than protein content during the entire cultivation period. In December and January, the chlorophyll content was maintained from 0.5 to $0.6 \mathrm{mg} \mathrm{g}^{-1}$ fresh algal weight, which was $75-85 \%$ of that in November. In the late stage of cultivation, the percentage of total chlorophyll in the algae was only about $35 \%$. 
In contrast to the variation of protein and chlorophyll, the content of cell wall hydrolytic polysaccharides increased with cultivation periods. The content of cell wall hydrolytic polysaccharides in March reached three times that of the first algae harvest. The most pronounced up-regulation was recorded in December and it was twice that in the previous November samples. After which the up-regulation trend slowed, with no significant difference between the March and February samples.

\subsection{ABA Content of the Samples under the Different Cultivation Periods}

The ABA content was about $10 \mathrm{ng} \mathrm{g}^{-1}$ protein in the algae collected from November to December (Figure 4), while the ABA content showed a sustained increase with the cultivation period in the following three months; the maximal value was twice the level found in November.

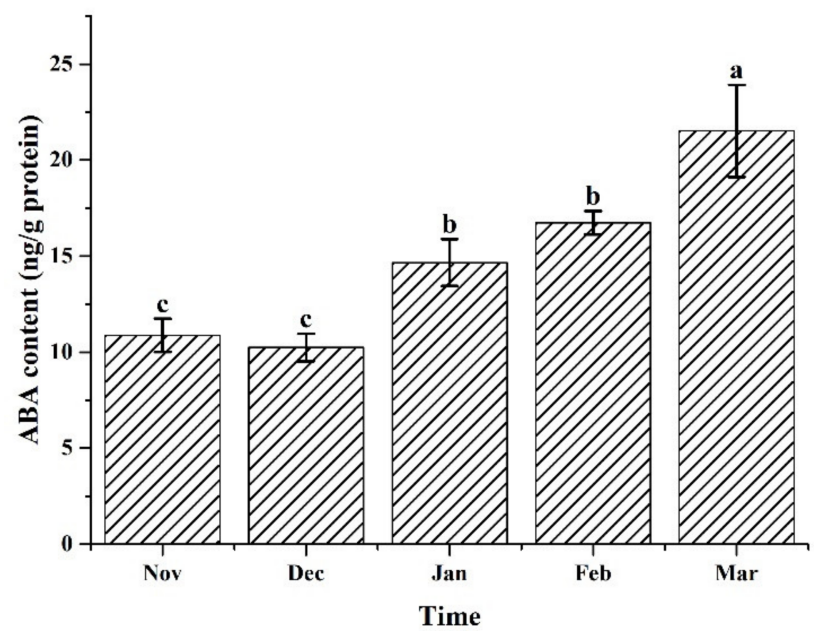

Figure 4. ABA content of $N$. yezoensis in different samples. Data were Mean $\pm \operatorname{SD}(n=3)$. Different letters indicated significant differences $(p<0.05)$.

\subsection{Changes to the Antioxidase Activities under Different Cultivation Periods}

As shown in Figure 5a, the NOX activity presented relatively stable activity during the first three months of cultivation. On the contrary, it presented a visible increase from February to March. The total antioxidant capacity in the algae increased significantly in December compared with that in November. It maintained relative stability until January of the following year and was up-regulated obviously in February and this trend of increasing continued until the end of the cultivation season (Figure $5 b$ ). Both the activity of SOD and APX presented a continuous increase with the extension of cultivation time (Figure $5 c, e$ ). Notably, there were also two significant upregulations in December and February. The change of CAT activity throughout the cultivation periods showed a similar trend to that of SOD (Figure 5d). Specifically, except for a slight decrease in March, it remained at a relatively high level. As shown in Figure 5f, the significance of POD activity was relatively stable during different cultivation periods. There was only one obvious up-regulation that occurred in December. 

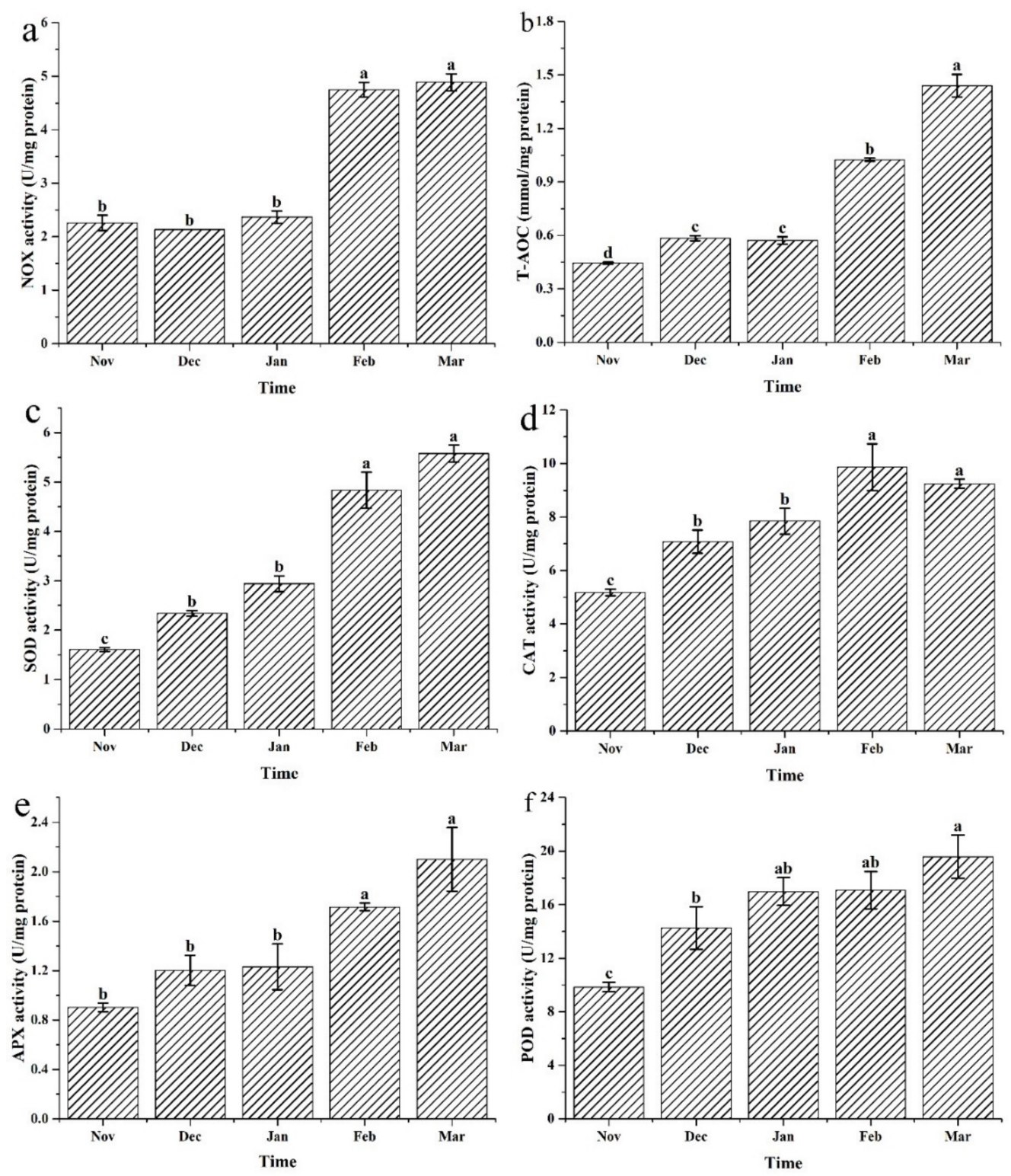

Figure 5. Changes of certain antioxidant enzymes in $N$. yezoensis collected from different cultivation periods. (a) NADH oxidase (NOX); (b) Total antioxidant capacity (T-AOC); (c) Superoxide dismutase (SOD); (d) Catalase (CAT); (e) Ascorbate peroxidase (APX); (f) Peroxidases (POD). Data were Mean $\pm \mathrm{SD}(n=3)$. Different letters indicated significant differences $(p<0.05)$.

\subsection{Antioxidase Genes Expression Profiles Determined by qRT-PCR}

Four crucial genes related to ROS production and scavenging were analyzed by qRTPCR to study the expression profiles of the antioxidase system under different cultivation periods (Figure 6). The results showed that their expression levels were consistent with a continually increasing trend but there was an anomalous increase in January in NOX and APX. In addition, a small downregulation was detected in SOD and NOX in the December samples. 

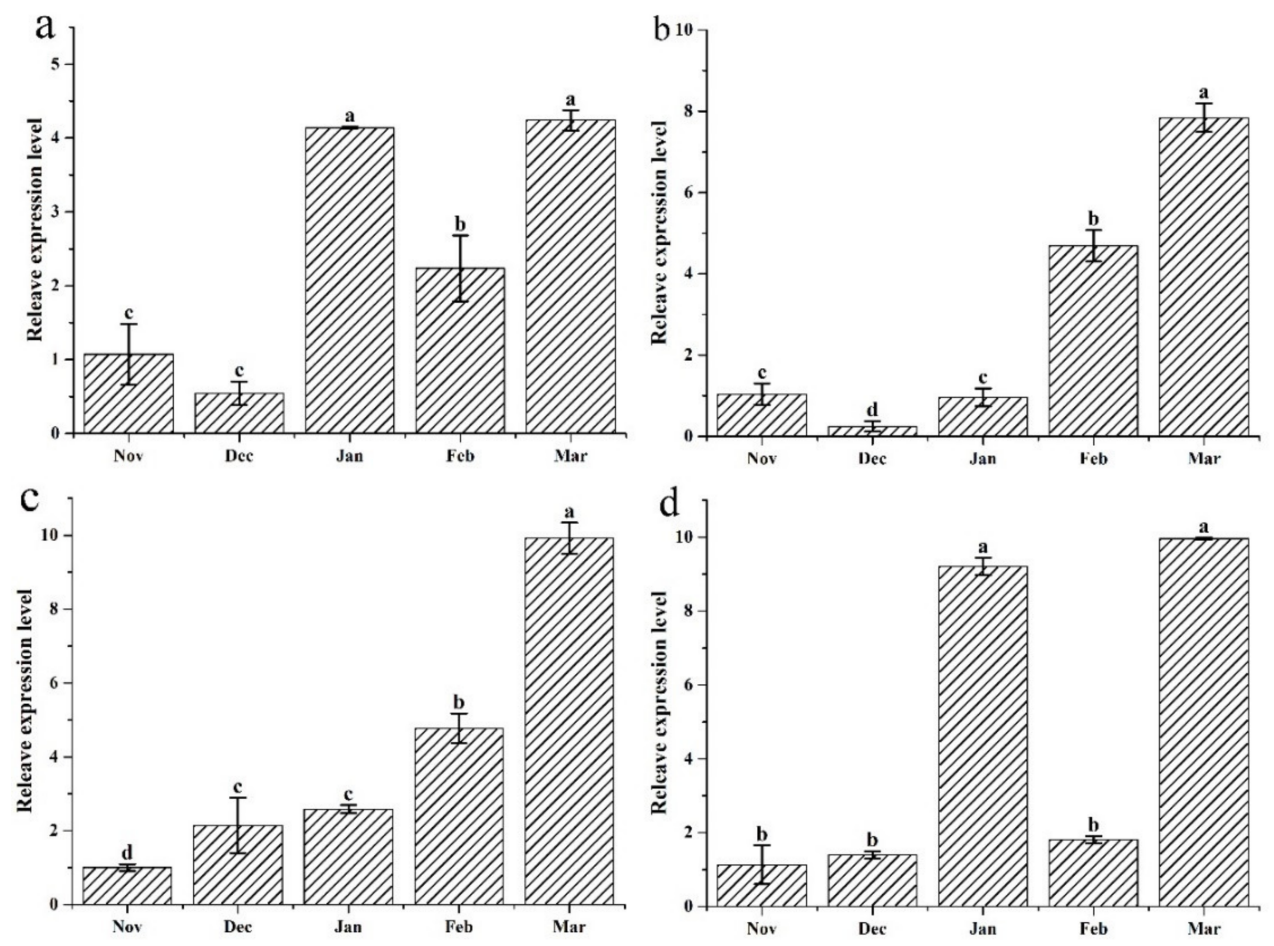

Figure 6. Expression of antioxidant enzyme genes in N. yezoensis collected from different cultivation periods. (a) NADH oxidase (NOX), (b) Superoxide dismutase (SOD), (c) Catalase (CAT), (d) Ascorbate peroxidase $(\mathrm{APX})$. Data were Mean $\pm \mathrm{SD}(n=3)$. Different letters indicated significant differences $(p<0.05)$.

\subsection{Variations in $\mathrm{H}_{2} \mathrm{O}_{2}, \mathrm{MDA}$ and $M A$ As Contents with the Cultivation Period}

As shown in Figure 7, the $\mathrm{H}_{2} \mathrm{O}_{2}$ content and MDA content seemed to present opposite variations. The $\mathrm{H}_{2} \mathrm{O}_{2}$ level in the algae decreased gradually but increased compared with that in February, whereas the MDA content increased obviously in December and maintained a relatively high level until the end of the cultivation. Overall, these two parameters did not show any drastic fluctuations. However, the relative contents of MAAs presented a sustained up-regulation, except for the last sample of March.
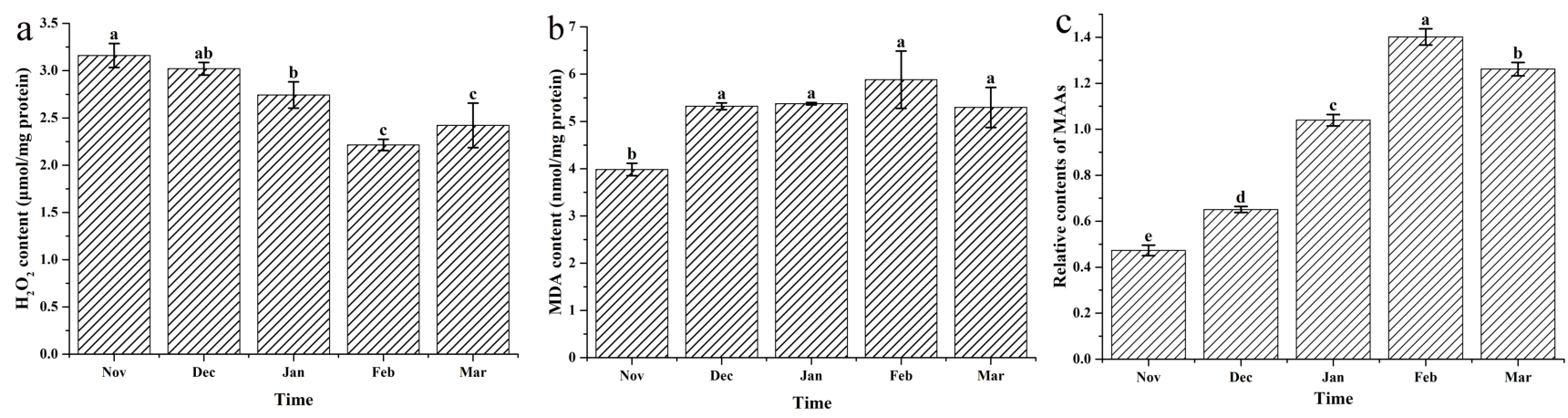

Figure 7. Variations of $\mathrm{H}_{2} \mathrm{O}_{2}$ and MDA in $N$. yezoensis collected from different cultivation periods. (a) $\mathrm{H}_{2} \mathrm{O}_{2}$ content, (b) MDA content, (c) Relative contents of MAAs. Data were Mean $\pm \mathrm{SD}(n=3)$. Different letters indicated significant differences $(p<0.05)$.

\section{Discussion}

\subsection{Sampling at Different Cultivation Periods}

Neopyropia is believed to be a marine crop shaped by stress and the success of this alga is due, in part at least, to its high tolerance to stress [7]. During the cultivation process, the nets that harbor algae need to be lifted from the seawater according to the growth 
status and the degree of contamination by fouling organisms and sludge. By the dry-out treatment, attached materials, such as harmful green algae, diatoms, various epiphytes, and soil deposited on the algae, are cleared during rehydration. Meanwhile, the physiological state of Neopyropia is recovered rapidly. The most significant response of the algae to dehydration is the production of ROS, which may be accompanied by temperature shock, strong light, and osmotic stresses [23]. There are also a series of physiological responses including ABA synthesis, up-regulation of antioxidants, and regulation of gene expression. The purpose of this study was to focus on the profile of stress response throughout the cultivation season. Therefore, attention should be paid to avoid the abnormal changes of some stress responding values due to the occurrence of stress conditions. To this end, all the samples collected were from cultivations that had been completely immersed for several days and were about to be harvested. Thus, the effects of dehydration derived from daily management should be avoided as much as possible.

Throughout the cultivation season, temperatures dropped from $18{ }^{\circ} \mathrm{C}$ to near freezing slowly and remained below $4{ }^{\circ} \mathrm{C}$ for about three weeks from the end of December to mid-January (Figure 1). Fortunately, the samples in December were collected before the sharp temperature decline and the samples in January were collected after one week of maintenance at $4{ }^{\circ} \mathrm{C}$. Moreover, an abnormal up-regulation in the content of ABA and the activities of antioxidases were not found. Therefore, it was shown that the samples were not subjected to obvious temperature shock; the data correctly reflected the trends in the variation of antioxidases with the cultivation time.

\subsection{Antioxidant Enzymes Play an Important Role during Cultivation of N. yezoensis in Sea Areas}

Throughout the cultivation season, antioxidant enzyme activities were continuously up-regulated with cultivation time. This might be related to the dehydration treatments, response to environmental stresses, and periodic harvesting during cultivation. During the cultivation season, the dry-out treatment of daily management inevitably led to environmental stresses and thus caused the gradual increase of antioxidant enzymes (Figure 5). As shown by the decreasing of $\mathrm{H}_{2} \mathrm{O}_{2}$ content (Figure 7a), the antioxidant enzymes play an important role during cultivation of $N$. yezoensis. On the other hand, the blades of N. yezoensis were cut off from the middle when harvested, leaving the base to continue growing. However, each harvest would result in mechanical damage and thus cause the accumulation of ROS, and subsequent stress response including up-regulation of antioxidases.

Another factor affecting the antioxidant enzymes activities to be considered is the seawater temperature. It dropped from $18{ }^{\circ} \mathrm{C}$ to near freezing and increased again during the followed spring, only reached $10{ }^{\circ} \mathrm{C}$ before the end of the cultivation. This indicated that the water temperature was maintained within the appropriate temperature range of $N$. yezoensis growth [24]. Thus, the seaweed cultivation was not affected by obvious high-temperature stress. The distinct up-regulation of gene expression in NOX and APX (Figure 6) in January might be related to the low temperatures stress endured by the algae. While the light intensity records (Figure 2) showed that the photoinhibition in $N$. yezoensis usually occurred at noon in the Jimo aquatic farm [25]. Especially in March, the daily light intensity might seriously affect the photosynthesis of N. yezoensis and result in the accumulation of ROS. Even so, the MDA contents did not show obvious up-regulation compared with those in other months. This implied that ROS in the cell was strictly controlled by the anti-oxidation system and which illustrated the importance of antioxidant enzymes.

\subsection{The Up-Regulation of Antioxidant Enzymes May Be Regulated by ABA Signaling Pathway}

Neopyropia yezoensis is a typical intertidal Rhodophyta and is believed to possess ancestral features of primary photosynthetic eukaryotes [26]. Based on the analysis of results from liquid chromatography-mass spectrometry and EST information, Mikami et al. (2016) strongly suggested that ABA in N. yezoensis is synthesized via pathways similar to the indirect pathway in terrestrial plants. As the results obtained here, ABA content increases 
with the cultivation period (Figure 4). With regards to the protection mechanism of ABA against photosynthesis systems, earlier studies showed that ABA could promote the repair of the PS II complex inactivation in Chlamydomonas reinhardtii (Chlorophyta) under lowtemperature stress [27]. Other studies suggest that ABA may protect the photosynthetic system from ROS damage in C. reinhardtii [28] rather than directly improving photosynthetic activity. The effects of ABA on the induction of antioxidant responses in Pyropia orbicularis (Rhodophyta) have been evaluated and the results showed that the activation of antioxidant enzymes genes was regulated by ABA during desiccation [29]. Additionally, ABA could significantly increase the expression of SOD, CAT, GR, APX, MDAR, and GST in Platycladus orientalis (Spermatophyta) during $\mathrm{H}_{2} \mathrm{O}_{2}$ treatment [30]. Our previous studies showed that the inhibition of ABA synthesis significantly decreased $F_{v} / F_{m}$ under hypersaline conditions and this was counteracted with the application of exogenous ABA [31]. Based on gene structure and enzymatic activity results, the analysis from an evolutionary perspective revealed that there exists a kind of prototype ABA signaling pathway in the induction of antioxidases genes in $N$. yezoensis [31]. In fact, there was a positive correlation between the antioxidant enzyme activities (Figure 5) and the ABA contents (Figure 4). Taken together, the results imply an ABA-mediated up-regulation of antioxidase genes in N. yezoensis.

\subsection{Up-Regulation of Antioxidases Is Associated with the Accumulation of ROS Produced by NOX}

NADPH oxidase is a type of plasma membrane protein that transfers electrons from cytosolic NADPH/NADH to apoplastic oxygen leading to the production of $\mathrm{O}^{2-}$, which is believed to be the main ROS source when plants are subjected to stress [32]. Presently, numerous results have shown that the up-regulation of ABA increased drought and salt tolerance which was associated with $\mathrm{H}_{2} \mathrm{O}_{2}$ production via NOX [33]. It has been reported that when the NOX gene is disrupted, the ABA signaling pathway became impaired in mutant Arabidopsis (Magnoliophyta), whereas the physiological response could be rescued with the addition of exogenous $\mathrm{ABA}$ or $\mathrm{H}_{2} \mathrm{O}_{2}$ [34]. Researchers have identified two NADPH oxidase catalytic subunit genes that function in ABA-induced ROS production in Arabidopsis [34]. This is consistent with a previous finding that ABA accumulation in the leaves of maize triggers the increased generation of ROS by NOX, which, in turn, leads to the up-regulation of the antioxidant defense system through the ABA signaling pathway [35]. We also identified two NOX transcripts with up-regulated expression when the samples were subjected to high salinity stress [31]. Here, a marked up-regulation of the NOX activity from February to March meant that the $\mathrm{O}^{2-}$ content mediated by it would be up-regulated; this could cause an increase in antioxidase activities (Figure 5). Meanwhile, the ABA content (Figure 4) and the total antioxidant capacity (Figure 5b) showed a trend consistent with changes in NOX activity. Thus, as suggested in other species, NOX-mediated ROS production was involved in the ABA signaling pathway in $N$. yezoensis.

\subsection{Accumulation of ROS May Lead to Adjustment of Multiple Metabolic Pathways}

Besides the up-regulation of the antioxidase system caused by excessive ROS accumulation, ROS produced by NOX are well known as an important signal for plant growth, seed germination, development, cell wall formation, and other metabolic pathways due to their membrane-permeable characteristics [5]. Using an antisense technique to downregulate NOX activity in tomato plants, it was found that redox-related metabolisms shifted and multiple effects on plant development were recorded [36]. NOX mutants in Arabidopsis [37] and barley [38] display impaired plant growth. The ROS produced by NOX were believed to be involved in the growth of fucoid brown algal zygotes [39]. Moreover, the fundamental process of cell elongation was found to be required for appropriate spatiotemporal control of ROS production by NOX [40].

ROS bursts mediated by NOX usually present a rapid response; the amplitude, frequency, localization, and duration determine the specificity of the signaling pathway involved [40]. Indeed, the $\mathrm{H}_{2} \mathrm{O}_{2}$ burst was most likely to be an early response and partici- 
pate in a wide range of signal transduction pathways under stress conditions [5]. Three principal modes of regulation in gene expression by ROS are advocated. First, a ROS sensor was activated and regulated the expression of the target genes. Second, the components of pathways were directly oxidized by ROS and altered gene expression profiles. Finally, some transcription factors might be modified by ROS and this induces the inhibition or expression of target genes via the interaction of transcription factors with the cis-elements in the promoters [41]. Microarray analysis revealed that potential $\mathrm{H}_{2} \mathrm{O}_{2}$-responsive ciselements existed in Arabidopsis [42], which is in line with the proposed role of $\mathrm{H}_{2} \mathrm{O}_{2}$ as a ubiquitous signal molecule during the oxidative stress response. A recent study indicated that $\mathrm{H}_{2} \mathrm{O}_{2}$ functions as a second messenger in tomato plants and regulated the systemic expression of various genes [43]. It is tempting to speculate that the emergence of ROS did not alter the expression or metabolism of certain genes in N. yezoensis. Although, how a particular set of genes can be regulated downstream has yet to be elucidated.

\subsection{ROS Accelerated Cell Aging}

Accumulation of ROS causes oxidative damage in a variety of macromolecules and leads to a progressive loss in the functional efficiency of various cellular processes [44]. With high-resolution two-dimensional gel electrophoresis coupled with immunoblotting of the carbonylation protein, a protein oxidation marker, researchers have found that accumulated ROS can accelerate the oxidation of proteins and thus cause impairment of mitochondrial function [45]. Additionally, during the development of the whole life cycle of cells, the time-dependent loss or corruption of information in DNA had been related to the formation of ROS with the aging of cells [46]. The $\mathrm{O}^{2-}$ produced by plasma NOX can be converted to $\mathrm{H}_{2} \mathrm{O}_{2}$ by SOD in apoplasts. Hydrogen peroxide can then be converted to $\mathrm{OH}$. under the presence of transition metals such as $\mathrm{Cu}^{2+}$ or $\mathrm{Fe}^{2+}[47,48]$. There was convincing evidence that $\mathrm{OH} \cdot$ was the most reactive $\mathrm{ROS}$ and interacted directly with most target biomolecules [48]. Dehydration causes a burst of ROS and, despite tight control by the anti-oxidation system, ROS produced by NOX may still cause damage to biomolecules. The long-term accumulation of these injuries leads to cell aging unavoidably in N. yezoensis. In the spring, when the temperature gradually rose and the light intensity increased, the aging of N. yezoensis cells seemed to be accelerated. Although the specific mechanisms were not reported, we had reason to believe that there is a connection between light intensity and the accumulation of stress damage by ROS.

\subsection{Accumulation of ROS May Also Result in the Synthesis of Stress-Related Molecules}

In the long-term evolution process, plants have formed precision signal regulation mechanisms to achieve normal growth and enhance their stress tolerance or defensive ability [49]. It has also been found that the accumulation of proline plays an important role in the high salinity stress response and D1-pyrroline-5-carboxylate synthetase was a key biosynthesis enzyme. More importantly, the expression of this key enzyme was regulated by ROS [50]. For example, studies have suggested that N. yezoensis growing in the high tide area with higher content of proline have strong water loss resistance, while those in the middle and low tide area are more sensitive to dehydration [51]. This implied that the accumulation of proline was induced by ROS in N. yezoensis.

Mycosporine-like amino acids (MAAs), are usually regarded as UV absorbing substances, which can alleviate damage to the photosynthetic system. As shown in Figure 7c, the MAAs relative contents increased with the cultivation periods. This illustrated that the algae cultivated in Jimo aquatic farm suffered from the irradiance stress increasingly, which caused an adjustment of the metabolism in N. yezoensis. MAAs were also involved in the regulation of osmotic stress in marine algae [52]. Similar results are reported in cyanobacteria [53]. MAAs decreased with the extension of submergence time in Py. haitanensis and daily dehydration treatment could maintain the level [54]. The blades with a high MAA content have a stronger ability to endure both water loss and UVR radiation stress [55]. 


\subsection{Stress Conditions Enhanced the Synthesis of the Cell Wall}

In marine red macrophytes, the cell wall is a complex tightly integrated with proteins, proteoglycans, and polysaccharides mainly composed of agars, water-soluble sulfate galactose, and carrageenans [56]. As reported previously, porphyrin, which is related to agarose because it contains disaccharide units, might act as a cushion against stress [57] due to the high 3,6-anhydro galactose content usually leads to thicker solutions and greater tendencies to form gels [58]. It was reported that polysaccharide content varied greatly in different seasons and growth conditions [59]. Moreover, the algae samples with the greater exposure contained higher 3,6-anhydro galactose [58]. Another study advocated that the sulfated polysaccharide cell-wall complex protects algal cells from the extreme environmental conditions of the native habitat [60]. Under stress conditions when photosynthesis is limited, red microalgae Porphyridium sp. Synthesized more sulfated polysaccharides [61]. During dehydration, N. yezoensis cells are exposed to air and subjected to different stress conditions, including dehydration, temperature shock, and high solar radiation. Therefore, the dehydration treatment during cultivation significantly promotes the synthesis of cell wall contents in the algae. This was the reason that the algae harvested in the late stage were hardier.

The frequency and intensity of dehydration might determine the structure of the cell wall. Additional studies in Neopyropia leucostricta (formerly Porphyra leucostricta) demonstrated that variations in porphyrin structure might be due to the lack of protoplasmic components in wall preparations or culture conditions and maturity [62]. It was also found that high light reduced the amounts of thylakoids and produced negative effects on the synthesis of chlorophyll in chloroplasts [63]. During the spring, the light intensity gradually increased (Figure 2), which inevitably caused a decrease in the amounts of thylakoids and chlorophyll (Figure 3b). In conclusion, the gradual enhancement of light intensity in the later stage leads to the reduction of chlorophyll, reduced protein accumulation, and up-regulated cell wall formation by sulfated polysaccharide synthesis.

\subsection{Potential Factors of ROS Induction and the Influences on N. yezoensis Cultivated in the Sea}

During one harvest cycle of $N$. yezoensis from autumn to the following spring, the algae suffer multiple environmental stresses, consists of temperature shock, cold, salt, dehydration and irradiance stresses. In addition, the regular or irregular dehydration treatment of the nets also made the algae bodies experience stress from water loss. The periodically harvesting during cultivation also causes mechanical damage to algal bodies. All these factors will cause the accumulation of ROS.

Although antioxidant enzymes protect cells from death or collapse during the entire cultivation season, the shift of gene expression during metabolism adjustment, upregulation of polysaccharides that constitute the cell wall, stress-related molecules like MAA and proline, and even the aging of cells in N. yezoensis, are believed to occur due to the induction of ROS. The strong radiation decreased the level of chlorophyll content (Figure $3 b$ ) and eventually led to lower carbon assimilation and a reduction of $\mathrm{NAD}(\mathrm{P}) \mathrm{H}$. Synthesis of molecules related to the stress response consumed large amounts of metabolic intermediates and energy, eventually resulting in reduced protein synthesis, just as was determined here (Figure 3a).

To sum up, the induction of ROS and the up-regulation of antioxidant enzymes through the ABA signaling pathway played a pivotal role in regulating the multiple stress response mechanism, and the dehydration treatment of nets harboring N. yezoensis, which are widely used in cultivation, are therefore a double-edged sword. The appropriate treatment can remove the attached epiphytes and promote the antioxidant ability in $N$. yezoensis cells. However, excessive dehydration can promote the aging of algae bodies and decrease the quality of $N$. yezoensis. 


\section{Conclusions}

Antioxidant enzymes played a pivotal role during the cultivation of $N$. yezoensis. Both the expression and the activities were up-regulated during the process of cultivation. During the entire cultivation season in Jimo sea area, the seawater temperature did not constitute a major environmental stress to $\mathrm{N}$. yezoensis. However, irradiation was believed to cause photoinhibition at noon, especially in March. Even under the most stressed conditions, the content of $\mathrm{H}_{2} \mathrm{O}_{2}$ and MDA was restricted to a relatively low level due to the continual up-regulation of antioxidases. However, all stress responses were accompanied by inevitable ROS accumulation that was also involved in the regulation of gene expression during metabolism adjustment, up-regulation of cell wall polysaccharides and stressrelated molecules like MAA and proline and in the aging of cells. In other words, to delay the maturity and aging of $N$. yezoensis cells, the production of ROS should be avoided as much as possible. Thus, it is proposed that the dry-out treatment of the N. yezoensis nets should be adopted when necessary and the extent of dehydration should be paid special consideration to prevent an excessive response or aging of cells caused by ROS. Moreover, we suggest that in N. yezoensis cultivated in the north Shandong coastal area, the cultivation raft with $N$. yezoensis should be lowered according to the irradiation conditions in spring to avoid an excessive stress response in cells caused by ROS.

Author Contributions: J.N. and G.W. conceived and designed research. Z.F., Z.S., and J.Y. conducted the experiments. J.N., J.Y., L.W. and G.L. analyzed the data. J.N., L.W. and Z.F. wrote the manuscript. G.W. checked and revised the manuscript. J.N. and G.W. serve as the author who were responsible for contact and ensuring communication. All authors have read and agreed to the published version of the manuscript.

Funding: This study was funded by the National Natural Science Foundation of China (Nos. 41776150, 41476140), China Agriculture Research System of MOF and MARA, the Key Deployment Project of the Centre for Ocean Mega-Research of Science, the Chinese Academy of Sciences (COMS2019Q02), and the Major Scientific and Technological Innovation Project of Shandong Provincial Key Research and Development Program (2019JZZY010815).

Institutional Review Board Statement: Not applicable.

Informed Consent Statement: Not applicable.

Data Availability Statement: The data presented in the study are deposited in the Oceanographic Data Center, accession number PAPER2022010007-01.

Conflicts of Interest: The authors declare no conflict of interest.

\section{References}

1. Huang, H.L.; Ullah, F.; Zhou, D.X.; Yi, M.; Zhao, Y. Mechanisms of ROS Regulation of Plant Development and Stress Responses. Front. Plant Sci. 2019, 10, 800. [CrossRef] [PubMed]

2. Waszczak, C.; Carmody, M.; Kangasjarvi, J. Reactive Oxygen Species in Plant Signaling. Annu. Rev. Plant Biol. 2018, 69, $209-236$. [CrossRef] [PubMed]

3. Liu, Y.K.; He, C.Z. Regulation of plant reactive oxygen species (ROS) in stress responses: Learning from AtRBOHD. Plant Cell Rep. 2016, 35, 995-1007. [CrossRef]

4. Moon, E.Y.; Oh, J.M.; Kim, Y.H.; Ryoo, I.J.; Yoo, I.D. Clitocybins, Novel Isoindolinone Free Radical Scavengers, from Mushroom Clitocybe aurantiaca Inhibit Apoptotic Cell Death and Cellular Senescence. Biol. Pharm. Bull. 2009, 32, 1689-1694. [CrossRef]

5. Chen, Q.H.; Yang, G.W. Signal Function Studies of ROS, Especially RBOH-Dependent ROS, in Plant Growth, Development and Environmental Stress. J. Plant Growth Regul. 2020, 39, 157-171. [CrossRef]

6. Sutherland, J.E.; Lindstrom, S.C.; Nelson, W.A.; Brodie, J.; Lynch, M.D.J.; Hwang, M.S.; Choi, H.G.; Miyata, M.; Kikuchi, N.; Oliveira, M.C.; et al. A New Look at an Ancient Order: Generic Revision of the Bangiales (Rhodophyta). J. Phycol. 2011, 47, 1131-1151. [CrossRef] [PubMed]

7. Blouin, N.A.; Brodie, J.A.; Grossman, A.C.; Xu, P.; Brawley, S.H. Porphyra: A marine crop shaped by stress. Trends Plant Sci. 2011, 16, 29-37. [CrossRef]

8. Tijero, V.; Teribia, N.; Munoz, P.; Munne-Bosch, S. Implication of Abscisic Acid on Ripening and Quality in Sweet Cherries: Differential Effects during Pre- and Post-harvest. Front. Plant Sci. 2016, 7, 602. [CrossRef] 
9. Jiang, D.G.; Zhou, L.Y.; Chen, W.T.; Ye, N.H.; Xia, J.X.; Zhuang, C.X. Overexpression of a microRNA-targeted NAC transcription factor improves drought and salt tolerance in Rice via ABA-mediated pathways. Rice 2019, 12, 76. [CrossRef] [PubMed]

10. Nogueira, F.T.S.; de Rosa, V.E.; Menossi, M.; Ulian, E.C.; Arruda, P. RNA expression profiles and data mining of sugarcane response to low temperature. Plant Physiol. 2003, 132, 1811-1824. [CrossRef]

11. Asada, K. The water-water cycle in chloroplasts: Scavenging of active oxygens and dissipation of excess photons. Annu. Rev. Plant Phys. 1999, 50, 601-639. [CrossRef] [PubMed]

12. Baier, M.; Dietz, K.J. Alkyl hydroperoxide reductases: The way out of the oxidative breakdown of lipids in chloroplasts. Trends Plant Sci. 1999, 4, 166-168. [CrossRef]

13. Melis, A. Photosystem-II damage and repair cycle in chloroplasts: What modulates the rate of photodamage in vivo? Trends Plant Sci. 1999, 4, 130-135. [CrossRef]

14. Yu, B.; Yang, J.L.; Niu, J.F.; Wang, G. Antioxidant responses to hyperosmolarity stress in the intertidal Pyropia yezoensis (Bangiales, Rhodophyta). Algal Res. 2020, 48, 101930. [CrossRef]

15. Zhou, W.; Hu, C.; Lu, M.Q.; Xu, Q.G.; Yang, P.L.; Tian, N.C.; Deng, C.Y. Germplasm innovation and application of Porphyra yezoensis. J. Guangxi Acad. Sci. 2021, 37, 46-52.

16. Yao, X.C.; Qiu, C.J.; Mu, C.L. Study on nutritional components and seasonal variation of Porphyra yezoensis. Aquaculture 2002, 5 , 34-35.

17. Zhong, M.; Zhang, Y. Changes of main nutrients in Porphyra yezoensis at different harvest stages. Chin. Feed. 2003, $23,30-31$.

18. Qian, C.C.; Liu, A.C.; Huang, R.; Liu, Q.R.; Xu, W.K.; Zhong, S.; Yu, L. Quality control of marine big data-a case study of real-time observation station data in Qingdao. J. Oceanol. Limnol. 2019, 37, 1983-1993. [CrossRef]

19. Liu, G.; Lian, Y.X.; Gao, H.S.; Gao, H.S.; Bai, T.; Dong, L.; Chen, L. Numerical study on the formation of atmospheric duct during a sea-land breeze process in the nearshore of Qingdao. Mar. Forecast. 2021, 38, 19-26.

20. Arnon, D.I. Copper Enzymes in Isolated Chloroplasts-Polyphenoloxidase in Beta-Vulgaris. Plant Physiol. 1949, 24, 1-15. [CrossRef] [PubMed]

21. Livak, K.J.; Schmittgen, T.D. Analysis of relative gene expression data using real-time quantitative PCR and the 2(T)(-Delta Delta C) method. Methods 2001, 25, 402-408. [CrossRef] [PubMed]

22. Chen, H.Z.; Zhang, H.H.; Xu, K.; Xu, Y.; Ji, D.H.; Wang, W.L.; Chen, C.S.; Xie, C.T. The Generation Difference of UVR Absoring Compounds Mycosporine-like Amino Acids (MAAs) of Pyropia haitanensis. J. Jimei Univ. 2018, 23, 161-170.

23. Kaur, G.; Pati, P.K. Analysis of cis-acting regulatory elements of Respiratory burst oxidase homolog (Rboh) gene families in Arabidopsis and rice provides clues for their diverse functions. Comput. Biol. Chem. 2016, 62, 104-118. [CrossRef]

24. Zhu, J.; Yan, Y.X.; Ding, H.L.; Zhang, P.X.; Lu, C.Q.; Xu, Q.P. Color Atlas of Chinese Laver; China Agricultural Press: Beijing, China, 2016.

25. Niu, J.F.; Feng, J.H.; Xie, X.J.; Gao, S.; Wang, C.G. Involvement of cyclic electron flow in irradiance stress responding and its potential regulation of the mechanisms in Pyropia yezoensis. Chin. J. Oceanol. Limn. 2016, 34, 730-739. [CrossRef]

26. Mikami, K.; Mori, I.C.; Matsuura, T.; Ikeda, Y.; Kojima, M.; Sakakibara, H.; Hirayama, T. Comprehensive quantification and genome survey reveal the presence of novel phytohormone action modes in red seaweeds. J. Appl. Phycol. 2016, 28, 2539-2548. [CrossRef]

27. Saradhi, P.P.; Suzuki, I.; Katoh, A.; Sakamoto, A.; Sharmila, P.; Shi, D.J.; Murata, N. Protection against the photo-induced inactivation of the photosystem II complex by abscisic acid. Plant Cell Environ. 2000, 23, 711-718. [CrossRef]

28. Yoshida, K.; Igarashi, E.; Mukai, M.; Hirata, K.; Miyamoto, K. Induction of tolerance to oxidative stress in the green alga, Chlamydomonas reinhardtii, by abscisic acid. Plant Cell Environ. 2003, 26, 451-457. [CrossRef]

29. Guajardo, E.; Correa, J.A.; Contreras-Porcia, L. Role of abscisic acid (ABA) in activating antioxidant tolerance responses to desiccation stress in intertidal seaweed species. Planta 2016, 243, 767-781. [CrossRef] [PubMed]

30. Yao, X.M.; Ji, J.; Yue, J.Y.; Shi, S.Q.; Ou, C.; Jiang, Z.P.; Chang, E.M. Exogenous Abscisic Acid Modulates Reactive Oxygen Metabolism and Related Gene Expression in Platycladus orientalis under $\mathrm{H}_{2} \mathrm{O}_{2}$-Induced Stress. Russ. J. Plant Physiology. 2020, 67, 85-93. [CrossRef]

31. Yang, J.; Gu, L.W.; Feng, H.Z.; Yu, Z.B. Synthesis of Abscisic Acid in Neopyropia yezoensis and Its Regulation of Antioxidase Genes Expressions Under Hypersaline Stress. Front. Microbiol. 2022, 12, 775710. [CrossRef]

32. Lamb, C.; Dixon, R.A. The oxidative burst in plant disease resistance. Annu. Rev. Plant Phys. 1997, 48, 251-275. [CrossRef] [PubMed]

33. Zhang, Y.M.; Tan, J.L.; Guo, Z.F.; Lu, S.Y.; He, S.J.; Shu, W.; Zhou, B.Y. Increased abscisic acid levels in transgenic tobacco over-expressing 9 cis-epoxycarotenoid dioxygenase influence $\mathrm{H}_{2} \mathrm{O}_{2}$ and $\mathrm{NO}$ production and antioxidant defences. Plant Cell Environ. 2009, 32, 509-519. [CrossRef]

34. Kwak, J.M.; Mori, I.C.; Pei, Z.M.; Leonhardt, N.; Torres, M.A.; Dangl, J.L.; Bloom, R.E.; Bodde, S.; Jones, J.D.G.; Schroeder, J.I. NADPH oxidase AtrbohD and AtrbohF genes function in ROS-dependent ABA signaling in Arabidopsis. EMBO J. 2003, 22, 2623-2633. [CrossRef]

35. Jiang, M.Y.; Zhang, J.H. Water stress-induced abscisic acid accumulation triggers the increased generation of reactive oxygen species and up-regulates the activities of antioxidant enzymes in maize leaves. J. Exp. Bot. 2002, 53, 2401-2410. [CrossRef] [PubMed] 
36. Sagi, M.; Davydov, O.; Orazova, S.; Yesbergenova, Z.; Ophir, R.; Stratmann, J.W.; Fluhr, R. Plant respiratory burst oxidase homologs impinge on wound responsiveness and development in Lycopersicon esculentum. Plant Cell 2004, 16, 616-628. [CrossRef] [PubMed]

37. Torres, M.A.; Dangl, J.L.; Jones, J.D.G. Arabidopsis gp91(phox) homologues AtrbohD and AtrbohF are required for accumulation of reactive oxygen intermediates in the plant defense response. Proc. Natl. Acad. Sci. USA 2002, 99, 517-522. [CrossRef]

38. Proels, R.K.; Oberhollenzer, K.; Pathuri, I.P.; Hensel, G.; Kumlehn, J.; Huckelhoven, R. RBOHF2 of Barley Is Required for Normal Development of Penetration Resistance to the Parasitic Fungus Blumeria graminis f. sp hordei. Mol. Plant-Microbe Interact. 2010, 23, 1143-1150. [CrossRef] [PubMed]

39. Coelho, S.M.B.; Brownlee, C.; Bothwell, J.H.F. A tip-high, $\mathrm{Ca}^{2+}$-interdependent, reactive oxygen species gradient is associated with polarized growth in Fucus serratus zygotes. Planta 2008, 227, 1037-1046. [CrossRef]

40. Marino, D.; Dunand, C.; Puppo, A.; Pauly, N. A burst of plant NADPH oxidases. Trends Plant Sci. 2012, 17, 9-15. [CrossRef] [PubMed]

41. Apel, K.; Hirt, H. Reactive oxygen species: Metabolism, oxidative stress, and signal transduction. Annu. Rev. Plant Biol. 2004, 55, 373-399. [CrossRef] [PubMed]

42. Desikan, R.; Mackerness, S.A.H.; Hancock, J.T.; Neill, S.J. Regulation of the Arabidopsis transcriptome by oxidative stress. Plant Physiol. 2001, 127, 159-172. [CrossRef] [PubMed]

43. Orozco-Cardenas, M.L.; Narvaez-Vasquez, J.; Ryan, C.A. Hydrogen peroxide acts as a second messenger for the induction of defense genes in tomato plants in response to wounding, systemin, and methyl jasmonate. Plant Cell 2001, 13, 179-191. [CrossRef] [PubMed]

44. Muller, F.L.; Lustgarten, M.S.; Jang, Y.; Richardson, A.; van Remmen, H. Trends in oxidative aging theories. Free Radic. Bio. Med. 2007, 43, 477-503. [CrossRef]

45. Qin, G.Z.; Meng, X.H.; Wang, Q.; Tian, S.P. Oxidative Damage of Mitochondrial Proteins Contributes to Fruit Senescence: A Redox Proteomics Analysis. J. Proteome Res. 2009, 8, 2449-2462. [CrossRef] [PubMed]

46. Hasty, P.; Campisi, J.; Hoeijmakers, J.; van Steeg, H.; Vijg, J. Aging and genome maintenance: Lessons from the mouse? Science 2003, 299, 1355-1359. [CrossRef]

47. Fry, S.C. Oxidative scission of plant cell wall polysaccharides by ascorbate-induced hydroxyl radicals. Biochem. J. 1998, 332, 507-515. [CrossRef] [PubMed]

48. Barry, H.; Gutteridge, J.M.C. Free radicals in biology and medicine. Pergamon 1991, 10, 449-450. [CrossRef]

49. Meng, X.Z.; Zhang, S.Q. MAPK Cascades in Plant Disease Resistance Signaling. Annu. Rev. Phytopathol. 2013, 51, 245-266. [CrossRef] [PubMed]

50. Rejeb, K.B.; Vos, D.L.; le Disquet, I.; Leprince, A.S.; Bordenave, M.; Maldiney, R.; Jdey, A.; Abdelly, C.; Savoure, A. Hydrogen peroxide produced by NADPH oxidases increases proline accumulation during salt or mannitol stress in Arab. Thaliana. New Phytol. 2015, 208, 1138-1148. [CrossRef]

51. Smith, C.M.; Berry, J.A. Recovery of Photosynthesis after Exposure of Intertidal Algae to Osmotic and Temperature Stresses Comparative-Studies of Species with Differing Distributional Limits. Oecologia 1986, 70, 6-12. [CrossRef] [PubMed]

52. Portwich, A.; Garcia-Pichel, F. A novel prokaryotic UVB photoreceptor in the cyanobacterium Chlorogloeopsis PCC 6912. Photochem. Photobiol. 2000, 71, 493-498. [CrossRef]

53. Liu, Z.W.; Hader, D.P.; Sommaruga, R. Occurrence of mycosporine-like amino acids (MAAs) in the bloom-forming cyanobacterium Microcystis aeruginosa. J. Plankton Res. 2004, 26, 963-966. [CrossRef]

54. Zhang, H.H. Preliminary Analysis on the Mechanism of UV Absorbing Substances of Porphyra haitanensis under Stress; Jimei University: Xiamen, China, 2016.

55. Jiang, H.X.; Gao, K.S.; Helbling, E.W. UV-absorbing compounds in Porphyra haitanensis (Rhodophyta) with special reference to effects of desiccation. J. Appl. Phycol. 2008, 20, 387-395. [CrossRef]

56. Lechat, H.; Amat, M.; Mazoyer, J.; Buleon, A.; Lahaye, M. Structure and distribution of glucomannan and sulfated glucan in the cell walls of the red alga Kappaphycus alvarezii (gigartinales, rhodophyta). J. Phycol. 2000, 36, 891-902. [CrossRef]

57. Eppley, R.W.; Cyrus, C.C. Cation Regulation and Survival of the Red Alga, Porphyra-Perforata, in Diluted and Concentrated Sea Water. Biol. Bull. 1960, 118, 55-65. [CrossRef]

58. Rees, D.A. Enzymic Synthesis of 3 6-Anhydro-L-Galactose within Porphyran from L-Galactose 6-Sulphate Units. Biochem. J. 1961, 81, 347. [CrossRef] [PubMed]

59. Rees, D.A. Estimation of Relative Amounts of Isomeric Sulphate Esters in Some Sulphated Polysaccharides. J. Chem. Soc. 1961, 5168-5171. [CrossRef]

60. Tannin-Spitz, T.; Bergman, M.; van-Moppes, D.; Grossman, S.; Arad, S. Antioxidant activity of the polysaccharide of the red microalga Porphyridium sp. J. Appl. Phycol. 2005, 17, 215-222. [CrossRef]

61. Adda, M.; Merchuk, J.C.; Arad, S. Effect of Nitrate on Growth and Production of Cell-Wall Polysaccharide by the Unicellular Red Alga Porphyridium. Biomass 1986, 10, 131-140. [CrossRef]

62. Gretz, M.R.; Mccandless, E.L.; Aronson, J.M.; Sommerfeld, M.R. The Galactan Sulfates of the Conchocelis Phases of Porphyra leucostricta and Bangia atropurpurea (Rhodophyta). J. Exp. Bot. 1983, 34, 705-711. [CrossRef]

63. Lichtenthaler, H.K.; Burgstahler, R.; Buschmann, C.; Meier, D.; Prenzel, U.; Schönthal, A. Effect of High Light and High Light Stress on Composition, Function and Structure of the Photosynthetic Apparatus; Springer: Berlin/Heidelberg, Germany, 1983. 